Прокопів М.M.

\title{
Якість життя мешканців мегаполісу, що перенесли церебральний інсульт
}

\author{
Національний медичний університет імені О.О. Богомольця, м. Київ, Україна
}

prokopivmm@gmail.com

Прокопив М.M.

Качество жизни жителей мегаполиса, перенесших церебральный инсульт

Национальный медицинский университет имени А.А. Богомольца, г. Киев, Украина
Prokopiv M.M.

Quality of life of the megapolis residents who suffered from cerebral stroke

National medical university named after O.O. Bohomolets, Kyiv, Ukraine

\section{Вступ}

Інсульт є однією 3 провідних причин смертності та довготривалої втрати працездатності у всьому світі. Значними $є$ й економічні витрати на лікування та догляд за пацієнтами, що перенесли інсульту. Кожні дві секунди в когось у світі трапляється інсульт [1-5]. За даними Всесвітньої організації охорони здоров'я, 15 млн людей щороку страждають на інсульт. 3 них 5 млн вмирають, а ще 5 млн стає інвалідами [6]. Інсульт вражає все більшу кількість молодих людей в країнах з низьким і середнім рівнем доходу [5,7]. Найвища захворюваність на інсульт реєструється у Східній Азії, східноєвропейському регіоні, а найнижча - у центральній Латинській Америці $[7,8]$.

Мета роботи - дослідити якість життя мешканців магаполісу працездатного віку, які перенесли ішемічний церебральний інсульт.

\section{Матеріали та методи}

При проведені дослідження використано соціологічний метод. 3 використанням адаптованої версії стандартизованого опитувальника SF-36 було опитано 427 мешканців м. Києва працездатного віку, які перенесли ішемічний церебральний інсульт. Всі респонденти не являються інвалідами. Когорта обстежених розділена на три групи: особи, що пройшли повний курс після стаціонарної реабілітації (54 - 12,6\%), особи, що пройшли частково після стаціонарну реабілітацію (217 - 50,8\%), особи, що не проходили після стаціонарну реабілітацію (156 - 36,6\%). Дані про респондентів наведено в табл. 1.

Респонденти анонімно заповнювали роздані їм адаптовані версії опитувальника SF-36, тривалість заповнення анкет в середньому складала 20-25 хвилин. Статистичну обробку отриманих результатів проводили 3 використанням загальноприйнятих медико-статистичних методів зі створеним масиву первинних даних 3 допомогою програми Statistica 6.0 та Microsoft Excel. Участь у дослідженні була добровільною. Конфеденційність даних про респондентів збережена.

Таблиця 1. Дані про респондентів, які прийняли участь в досліджені

\begin{tabular}{|l|c|c|}
\hline \multicolumn{1}{|c|}{$\begin{array}{c}\text { Показник } \\
\text { Особи, що пройшли повний курс }\end{array}$} & $\%$ \\
\hline \multicolumn{2}{|c|}{ післястаціонарної реабілітації (n = 54) } \\
\hline Чоловіки & 21 & 38,9 \\
\hline Жінки & 33 & 61,1 \\
\hline Продовжували працювати & 31 & 57,4 \\
\hline Не працюють & 23 & 42,6 \\
\hline \multicolumn{2}{|c|}{ Особи, що пройшли частково } \\
\hline післястаціонарну реабілітацію (n = 217) \\
\hline Чоловіки & 82 & 37,8 \\
\hline Жінки & 135 & 62,2 \\
\hline Продовжували працювати & 96 & 44,2 \\
\hline Не працюють & 121 & 55,8 \\
\hline \multicolumn{2}{|c|}{ Особи, що не проходили } \\
\hline післястаціонарну реабілітацію (n = 156) \\
\hline Жоловіки & 64 & 41,0 \\
\hline Жінки & 92 & 59,0 \\
\hline Продовжували працювати & 72 & 46,2 \\
\hline Не працюють & 84 & 53,8 \\
\hline
\end{tabular}

Науковою базою дослідження стали сімейні амбулаторії м. Києва, в яких надається медична допомога хворим які перенесли церебральний інсульт. Методичною основою дослідження став системний підхід, 3 комплексним використанням структурно-логічного аналізу, медико-статистичного та соціологічного (анкетного опитування) методів. 


\section{Результати дослідження та їх обговорення}

Отримані в ході дослідження результати були опрацьовані з використанням статистичного методу та проаналізовані 3 використанням методу структурнологічного аналізу. Отримані результати щодо фізичної компоненти здоров'я наведено в табл. 2.

Проведена оцінка отриманих результатів дослідження фізичного компоненту якості життя виявила найбільшу розбіжність в показниках між першою i третьою групами дослідження за шкалами фізичного здоров'я та загального сприйняття здоров'я (GH).

В ході дослідження встановлено, що майже половина респондентів 3 третьої групи дослідження оцінили стан особистого здоров'я як посередній. Так, у $46,15 \pm 2,5 \%$ опитаних такий стан здоров'я в значній мірі обмежує їх у виконанні фізичних навантажень, а $12,6 \pm 1,9 \%$ оцінили особистий стан фізичного здоров'я як поганий. Більшість респондентів відмітили, що $(82,02 \pm 1,9 \%)$ обмежують себе у заняттях силовими видами спорту, у виконанні важких фізичних навантажень, третина $(25,4 \pm 2,2 \%)$ намагаються уникати фізичних навантажень, оскільки відчувають себе обмеженими у їх виконанні, $3,5 \pm 0,9 \%$ не можуть одягнутися і помитися без сторонньої допомоги. При цьому в першій групі дослідження таких осіб не виявлено.

Отримані результати щодо психологічної компоненти здоров'я наведено в табл. 3.

Таблиця 2. Результати розрахунків оцінки фізичної компоненти здоров'я якості життя осіб, що перенесли ішемічний церебральний інсульт

\begin{tabular}{|c|c|c|c|c|}
\hline \multicolumn{2}{|r|}{ Шкали } & \multirow{2}{*}{$\begin{array}{c}\text { Особи, що пройшли } \\
\text { повний курс після } \\
\text { стаціонарної } \\
\text { реабілітації }(\mathbf{n}=\mathbf{5 4}) \\
81,48 \pm 2,0\end{array}$} & \multirow{2}{*}{$\begin{array}{c}\text { Особи, що пройшли } \\
\text { частково після } \\
\text { стаціонарну } \\
\text { реабілітацію }(\mathbf{n}=\mathbf{2 1 7}) \\
78,34 \pm 2,1\end{array}$} & \multirow{2}{*}{$\begin{array}{c}\text { Особи, що не } \\
\text { проходили після } \\
\text { стаціонарну } \\
\text { реабілітацію (n = 156) } \\
46,15 \pm 2,5\end{array}$} \\
\hline $\mathrm{PH}$ & Фізичне здоров'я & & & \\
\hline $\mathrm{PF}$ & Фізична активність & $77,77 \pm 2,1$ & $70,05 \pm 2,3$ & $51,92 \pm 2,5$ \\
\hline $\mathrm{RP}$ & $\begin{array}{l}\text { Значення фізичних проблем } \\
\text { в обмеженні життєдіяльності }\end{array}$ & $74,07 \pm 2,2$ & $82,02 \pm 1,9$ & $89,7 \pm 1,5$ \\
\hline $\mathrm{BP}$ & Фізичний біль & $70,37 \pm 2,3$ & $73,27 \pm 2,2$ & $78,2 \pm 2,0$ \\
\hline GH & Загальне сприйняття здоров’я & $85,18 \pm 1,8$ & $60,83 \pm 2,4$ & $53,21 \pm 2,5$ \\
\hline
\end{tabular}

Таблиця 3. Результати розрахунків оцінки психологічного компоненту здоров'я якості життя осіб, що перенесли ішемічний церебральний інсульт

\begin{tabular}{|c|c|c|c|c|}
\hline & Шкали & $\begin{array}{c}\text { Особи, що пройшли } \\
\text { повний курс після } \\
\text { стаціонарної } \\
\text { реабілітації }(n=54)\end{array}$ & $\begin{array}{c}\text { Особи, що пройшли } \\
\text { частково після } \\
\text { стаціонарну } \\
\text { реабілітацію }(\mathbf{n}=217)\end{array}$ & $\begin{array}{c}\text { Особи, що не } \\
\text { проходили після } \\
\text { стаціонарну } \\
\text { реабілітацію }(\mathrm{n}=\mathbf{1 5 6})\end{array}$ \\
\hline MH & $\begin{array}{l}\text { Психологічний компонент } \\
\text { здоров'я }\end{array}$ & $75,69 \pm 2,2$ & $59,45 \pm 2,5$ & $53,85 \pm 2,5$ \\
\hline VT & Життєва активність & $87,04 \pm 1,7$ & $56,68 \pm 2,5$ & $51,96 \pm 2,5$ \\
\hline SF & Соціальна активність & $76,78 \pm 2,1$ & $50,23 \pm 2,5$ & $46,15 \pm 2,5$ \\
\hline RE & $\begin{array}{l}\text { Значення емоційних проблем } \\
\text { в обмеженні життєдіяльності }\end{array}$ & $83,33 \pm 1,9$ & $46,54 \pm 2,5$ & $43,59 \pm 2,5$ \\
\hline $\mathrm{MH}$ & Психічне здоров’я & $75,92 \pm 2,2$ & $51,15 \pm 2,5$ & $46,15 \pm 2,5$ \\
\hline
\end{tabular}

Проведений аналіз психологічних компонентів якості життя осіб, що перенесли ішемічний інсульт виявив теж найбільшу розбіжність в показниках між першою i третьою групами дослідження за шкалами емоційних (RE) проблем в обмеженні життєдіяльності. В процесі дослідження встановлено, що порушений емоційних стан спонукає біля половини обстежених $(56,5 \pm 2,5 \%)$ респондентів із третьої групи обстеження виконувати менше, ніж хотілося б, а 72,9 $2,2 \%$ не можуть виконувати заплановану роботу так ретельно як завжди.

Необхідно зазначити, що фізичний та емоційний стан $21,5 \pm 2,1 \%$ опитаних сильно заважає проводити час 3 сім'єю, друзями сусідами або в колективі, а 24,3 $22,3 \%$ відмічають, що увесь час хвилюються, а відчуття бадьорого настрою мають $32,5 \pm 2,1 \%$ опитаних.

В цілому встановлено, що у респондентів, що перенесли ішемічний інсульт і пройшли повний комплекс реабілітації підсумковий рівень якості життя на $34,11 \%$ $(\mathrm{p}<0,001)$ вищий ніж у осіб, що реабілітацію не проходили.

Перспективи подальших досліджень пов'язані 3 вивченням якості життя осіб, які перенесли геморагічний інсульт в залежності від рівня проходження реабілітації. 


\section{Висновки}

Проведена оцінка рівня якості життя осіб працездатного віку, які проживають у мегаполісі i перенесли церебральний інсульт дозволила встановити статистично значущі відмінності фізичної та психологічної компоненти в залежності від рівня проходження після-стаціонарної реабілітації. Більш високий рівень якості життя мають особи, які в після стаціонарному періоді пройшли повний курс реабілітації, a низький рівень якості життя мають особи, які реабілітацію не проходили. Отримані результати є підгрунттям для запровадження системи реабілітаційної допомоги для осіб, які перенесли церебральний інсульт.

\title{
References
}

1. World Stroke Organization. Global Stroke Fact Sheet. 26.02.2019. Available from: https://www.world-stroke.org/ images/WSO_Global_Stroke_Fact_Sheet_final.pdf.

2. Vinychuk SM, Fartushna OYe. Cerebrospinal and commissural diaschisis in acute stroke patients: case analysis. International Neurological Journal. 2018;5(99):20-25. DOI: https://doi.org/10.22141/2224-0713.5.99.2018.142959.

3. Fartushna OYe, Vinychuk SM. Brain injury in patients with acute TIA: clinical features in different TIA subtypes. International Neurological Journal. 2017;3(89):13-18. DOI: https://doi.org/10.22141/2224-0713.3.89.2017.104238.

4. Vinychuk SM, Prokopiv MM. Gostryj ishemichnyj insul't [Acute ischemic stroke]. Kyiv: Naukova dumka; 2006. 286 p. (in Ukrainian) ISBN: 966-00-0615-2.

5. Fartushna OYe, Vinychuk SM. Tranzytorni ishemichni ataky [Transient Ischemic Attacks]. Kyiv: PH «Avitsena»; 2014. 216 p. (in Ukrainian). ISBN 978-966-2144-70-3.

6. Institute for Health Metrics and Evaluation (IHME). Findings from the Global Burden of Disease Study 2017. Seattle, WA: IHME, 2018.

7. GBD 2016 Causes of Death Collaborators. Global, regional, and national age-sex specific mortality for 264 causes of death, 1980-2016: a systematic analysis for the Global Burden of Disease Study 2016. Lancet. 2017;390(10100):1151-1210. DOI: http://doi.org/10.1016/S0140-6736(17)32152-9.

8. Fartushna OYe, Vinychuk SM. Epidemiology of transient ischemic attacks in the structure of acute cerebrovascular disorders in Ukraine and in other countries. International Neurological Journal. 2017;5 (91):105-111. (in Ukrainian). DOI: http://doi.org/10.22141/2224-0713.5.91.2017.110863.

Дата надходження рукопису до редакції: 16.01 .2020 p.

\begin{abstract}
Мета роботи - дослідити якість життя мешканців мегаполісу працездатного віку, які перенесли ішемічний церебральний інсульт.

Матеріали та методи. Методи дослідження: соціологічний, статистичний, структурно-логічного аналізу. 3 використанням адаптованої версії стандартизованого опитувальника SF-36 було опитано 427 мешканців м. Києва працездатного віку, які перенесли ішемічний церебральний інсульт. Обстежені розділені на три групи в залежності від рівня отримання реабілітаційних послуг.

Результати та обговорення. Проведена оцінка рівня якості життя осіб працездатного віку, які проживають у мегаполісі і перенесли церебральний інсульт дозволила встановити статистично значущі відмінності фізичної та психологічної компоненти в залежності від рівня проходження після-стаціонарної реабілітації. Більш високий рівень якості життя мають особи, які в після стаціонарному періоді пройшли повний курс реабілітації, а низький рівень якості життя мають особи, які реабілітацію не проходили.
\end{abstract}

Висновки. Отримані результати є підгрунттям для запровадження системи реабілітаційної допомоги для осіб, які перенесли церебральний інсульт.

Ключові слова: церебральний інсульт, реабілітація, якість життя.

Цель работы - изучить качество жизни жителей мегаполиса трудоспособного возраста, перенесших ишемический церебральный инсульт.

Материалы и методы. Методы исследования: социологический, статистический, структурно-логического анализа. С использованием адаптированной версии стандартизованного опросника SF-36 было опрошено 427 жителей г. Киев трудоспособного возраста, перенесших ишемический церебральный инсульт. Обследованные лица разделены на три группы в зависимости от уровня полученных реабилитационных услуг.

Результаты и обсуждение. Проведенная оценка уровня качества жизни лиц трудоспособного возраста, проживающих в мегаполисе и перенесших церебральный инсульт, позволила установить статистически значимые различия физической и психологической компоненты в зависимости от уровня прохождения после-стационарной реабилитации. Более высокий уровень качества жизни имеют лица, прошедшие в после-стационарном периоде полный курс реабилитации, а низкий уровень качества жизни имеют лица, не проходившие реабилитацию. 
Выводы. Полученные результаты являются основанием для введения системы реабилитационной помощи для лиц, перенесших церебральный инсульт.

Ключевые слова: церебральный инсульт, реабилитация, качество жизни. stroke.

Goal of research - to study the quality of life of megapolis residents of working age who underwent ischemic cerebral

Materials and methods. Methods of research: sociological, statistical, of structural-and-logical analysis. 427 inhabitants of Kyiv city of working age who underwent ischemic cerebral stroke were polled with the use of the adapted version of standardized questionnaire SF-36. The surveyed persons were divided into three groups depending on the level of rehabilitation services obtained.

Results and discussion. The assessment of the life quality of megapolis residents of working age, who underwent cerebral stroke, allowed to establish statistically significant differences of physical and psychological components depending on the level of obtained post-inpatient rehabilitation. Persons who underwent a complete rehabilitation course after inpatient period demonstrate higher level of quality of life, and those persons who has not been rehabilitated have low level of quality of life has.

Conclusions. The results obtained can be used as the base for the introduction of rehabilitation care system for those who have suffered from cerebral stroke.

Key words: cerebral stroke, rehabilitation, quality of life.

\section{Відомості про автора}

Прокопів Марія Мирославівна - кандидат медичних наук, доцент, доцент кафедри неврології Національного медичного університету імені О.О. Богомольця; м. Київ, бул. Т. Шевченка, 13.

+380 (66) 268-35-27, prokopivmm@gmail.com. 